\title{
Unstable Education System Inducing Mental Stress in COVID-19 Lockdown
}

\author{
Gurjant Singh \\ Maharishi Markandeshwar Institute of Physiotherapy and Rehabilitation, Mullana, Haryana, India
}

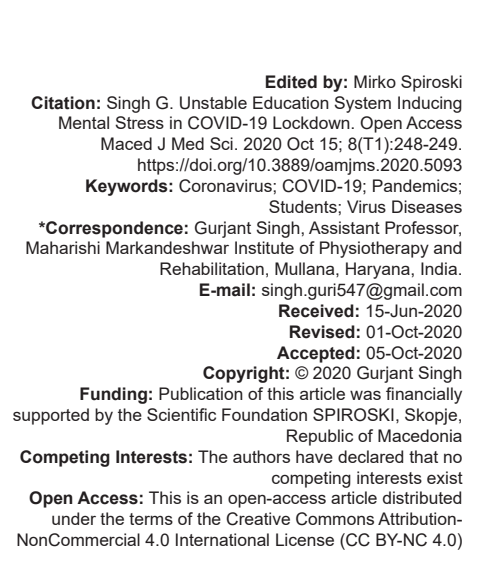

Abstract

Coronavirus disease or COVID-19 caused by SARS-CoV-2 has triggered a respiratory tract infection claiming more than 3 lakh lives worldwide with 4.5 million cases and still counting. This is the worst hit of the $21^{\text {st }}$ century which has made it to be announced as a pandemic by WHO on March 11, 2020. It is not possible at the time to comment if the virus has appeared all of a sudden or its gradual emerging in a short or long time with information passed lately. However, the virus has adjourned the life of humans in almost every aspect with most of the countries, including India announcing nationwide lockdowns. The news of progress over medicine or vaccine over days is no doubt giving hope to the stressed-out humanity which is being striked out again by some higher health officials warning that the coronavirus may never go away. Such news is always creating panic and claiming mental peace, building more stress in individuals. Amidst all these crisis, there is a field which took everyone's attention, that is the education of the students. However, Indians are always known to emerge out stronger in challenges, so did they, when it was the matter of future of the students. Although Indian education system is not much familiar to such measures, it was the call and need of the situation to clasp to a different mode of education effectively and efficiently. Even with this much dedication, there seem to be some points on which the education system is breaking down gradually without the awareness of many. This article has focused on a few of such challenges imposed by the COVID-19 lockdown on the education system in India.

\section{Adapting to a Mode of Delivering Education}

The majority of Indian education systems are more focused on the traditional mode of learning, one on one interaction between teacher and students. Physical presence of the teachers and the peer group sets the learning environment of the institutions [1]. Sudden suspension of such classes arose the need of some alternative methods like online classes through video conferencing platforms, delivering PowerPoint presentations, providing e-books, or even using phone calls to solve students' queries related to the subject. Even University Grants Commissions (UGC) has taken many initiatives to promote e-learning through online platforms [2]. However, it is not that easy as it appears to be. Switching to a different learning mode does not go swiftly for the students. It is difficult to accept such changes without preparedness. In many places in India, there is poor internet connectivity which further creates difficulty to cope up with online learning, especially in some rural areas. For the teachers, preparing a single lecture to be delivered online increases the workload even further [3], making them compromise with the study material even if they do not want to. However, they are forced to do it as the call of the situation to save the students' future and even because of mental pressure being built on them.

\section{Distracting Away from the Real Path}

Sometimes, "too much" is more precarious than "nothing." The same is going well with the current scenario of education in India. UGC, Indian Government, and respective institutions are taking recognizable steps to hold on to good education. However, this has brought a deluge of learning resources, making it difficult for the learners to choose between them. Without proper guidance and preparedness, everything looks similar and makes it difficult to adhere to some best ones according to their choice. Apart from the flood of learning resources, it has become a trend to conduct webinars on different topics. Every other day, there is a notification of some free webinars claiming to provide certification of attendance. Most of these webinars are unreliable and different from the subjective knowledge of the students which are distracting them from the actual path of learning the respective course.

\section{Conducting Examination}

The mid of an year in India is basically the time of conclusion for the students, well known as the time of 
final examinations for various courses. Coronavirus does not seem to be vanished in the near future, especially in a couple of months or so [4]. This is welcoming a new challenge of conducting examinations and concluding the annual year. Fear of failure is already on a peak for the students and unawareness of the exams may accelerate the underperformance of the students. Teachers are even not spared by this challenge, which is equally a situation of worry for them [5]. Evaluating a large number of students remotely is itself a difficult work and doing it without a well-defined medium is knocking on their mental peace [6].

\section{Financial Uncertainty and Emotional Distress}

Indian government has taken a wise step by requesting the private sectors to avoid deducting the salaries of their workers. Even with the hope of a cure to coronavirus in the near future, the reopening of educational institutions seems to be a long way to go. This is what directly or indirectly going to challenge the government's appeal of allowance of monthly income, including that for the teachers. Or it may have already been challenged in some private institutions with no such official reporting till now. This period of uncertainty on being paid for the even harder working and managing resources economically over the long run may raise the emotional distress among teachers [7]. With the threat of the same to happen soon or later, it might get difficult for them to give their best in the work they have been assigned.

With the hard work and dedication of government and private sectors, there is a ray of hope on getting back to normal life soon. However, the present conditions are really depressing. As a nation, there are worldwide signs of united India against this epidemic; still, there might be some sources looking for personal growth more over the basic regular proceedings and needs of their workers' life. Such sectors include the education sector also. Everybody is in a hurry to succeed with the newer methods of teaching and learning, unaware that we are deflecting from the real path of education. Nobody seems to be conscious about the mental stress being faced by students and teachers and nobody has raised a voice for it. Education does not really mean subjective learning only; it actually means mental development also. With the present circumstances, learners and educators are directly or indirectly being pushed toward some serious mental conditions which may build up into a mental illness, that for sure will be responsible for the undergrowth of the education system. This threat is being built up unawarely as a hidden threat after COVID-19 making it a misfortune for India [8].

\section{References}

1. Ammenwerth E, Hackl WO. Monitoring of students' interaction in online learning settings by structural network analysis and indicators. Stud Health Technol Inform. 2017;235:293-7.

PMid:28423801

2. Varalakshmi R, Arunachalam K. COVID 2019-Role of faculty members to keep mental activeness of students. Asian J Psychiatry. 2020;51:102091. https://doi.org/10.1016/j. ajp.2020.102091 PMid:32289726

3. The Hindu Group. E-education No Child's Play, Teachers Putting Tremendous Efforts in Online Classes: HC. Chennai: The Hindu Group; 2020. Available from: https://www.thehindu.com/ news/cities/Delhi/e-education-no-childs-play-teachers-puttingtremendous-efforts-in-online-classes-hc/article31454616.ece. [Last accessed on 2020 Apr 28].

4. Brooks SK, Webster RK, Smith LE, Woodland L, Wessely S, Greenberg N, et al. The psychological impact of quarantine and how to reduce it: Rapid review of the evidence. Lancet. 2020;395(10227):912-20. https://doi.org/10.1016/ s0140-6736(20)30460-8

5. Khan S, Khan RA. Online assessments: Exploring perspectives of university students. Educ Inform Technol. 2019;24(1):661-77. https://doi.org/10.1007/s10639-018-9797-0

6. Clark TM, Callam CS, Paul NM, Stoltzfus MW, Turner D. Testing in the time of COVID-19: A sudden transition to unproctored online exams. J Chem Educ. 2020;97(9):3413-7. https://doi. org/10.1021/acs.jchemed.0c00546

7. Farhana Z, Tanni SA, Shabnam S, Chowdhury SA. Secondary education during lockdown situation due to Covid-19 pandemic in Bangladesh: Teachers' response on online classes. J Educ Pract. 2020;11(20):97-102. https://doi.org/10.7176/jep/11-20-11

8. Shah S, Diwan S, Kohan L, Rosenblum D, Gharibo C, Soin A, et al. The technological impact of COVID-19 on the future of education and health care delivery. Pain Physician. 2020;23(4):S367-80. PMid:32942794 